Does the Jack of All Trades Hold the Winning Hand?: Comparing the Role of Specialized Versus General Skills in the Returns to an Agricultural Degree

Georgeanne M. Artz, Kevin Kimle, Peter Orazem

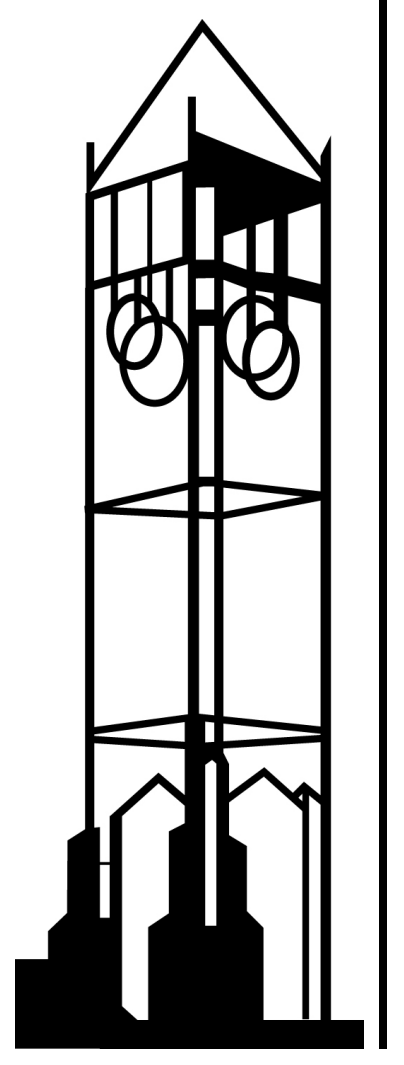

Working Paper No. 11021

November 2011

IOWA STATE UNIVERSITY

Department of Economics

Ames, lowa, 50011-1070 


\section{Does the Jack of All Trades Hold the Winning Hand?: Comparing the role of specialized versus general skills in the returns to an agricultural degree}

Georgeanne M. Artz, Visiting Assistant Professor, Economics, Iowa State University, gartz@iastate.edu

Kevin L. Kimle, Rastetter Chair of Agricultural Entrepreneurship, Iowa State University, kimle@iastate.edu

Peter F. Orazem, University Professor, Economics, Iowa State University, pfo@iastate.edu

\section{Abstract}

This paper examines the roles of specialized versus general skills in explaining variation in the returns to an agriculture degree across majors inside and outside the agricultural industry. The focus on returns by sector of employment is motivated by the finding that most agricultural majors are employed in non-agricultural jobs. A sample of alumni graduating from a large Midwestern Public University between 1982 and 2006 shows that alumni with majors more specialized in agriculture earned a premium from working in the agriculture industry, but this advantage has diminished over time. Agricultural majors with more general training earn more outside than inside agriculture, and their advantage has increased over time. During sectoral downturns in the agriculture economy, more specialized majors suffer large pay disadvantages compared to more generally trained agriculture majors and majors in other colleges. These findings suggest that greater levels of specialization may limit a graduate's ability to adjust to changing economic circumstances. Agriculture degree programs could benefit from curriculum innovations focused on developing more generalized skills.

JEL codes: J43, J31, A2

Key Words: Earnings, Agricultural sector, College Major, Business cycle, Curriculum, Specific Skills, General Skills, Urban, Rural 


\section{Does the Jack of All Trades Hold the Winning Hand?: Comparing the role of specialized versus general skills in the returns to an agricultural degree}

Agriculture is the \#1 most useless college degree according to an on-line article published recently by Yahoo; animal science and horticulture degrees ranked 4 th and $5^{\text {th }}$ on this list. These degrees are useless, the author contends, because they are "so specific they can't be applied in a variety of fields, or [are] linked to careers with virtually little to no projected job growth." As an example, the story characterizes an Animal Science degree as, "so specific that trying to apply it to anything else means a tough time convincing people it gives you any useful skills for jobs outside animal science." (Loose, 2012). In response, the Dean of the College of Food, Agricultural and Natural Resource Sciences at the University of Minnesota stated that, "animal scientists work in the medical, pharmaceutical, food safety, and finance fields, just to name a few... about half continue to graduate school where they study veterinary medicine, public health and biology"(Levine, 2012).

Issues regarding the specificity of skills imparted by agriculture majors relative to the needs of employers are not new. Indeed some commentators have argued, contrary to the Yahoo contention, that the agriculture major is insufficiently focused on the skills required by employers in the agriculture industry. As a result, agribusiness firms are increasingly hiring nonagriculture college graduates. In a 1992 National Research Council report, Agriculture and the undergraduate, a former corporate executive, Robert Goodman, wrote, "Today, those of us who hire research technicians in the private sector find young people with the skills and experience we need as often as not among graduates of programs in chemistry, life sciences, and chemical engineering, and we must absorb the cost of teaching them about agriculture on the job. This is not bad, because in my experience such people are quickly attracted to the importance and the 
intrinsic interest of agricultural research and development. Both of these observations raise the question of the relevance of having an undergraduate curriculum in agriculture" (p. 44).

Corroborating evidence is found in recent surveys of potential employers of agricultural college graduates that emphasize the importance of general qualifications such as oral communications skills and ability to work in a team setting over more technical or specialized knowledge of agriculture (Boland and Akridge, 2004; Onianwa, Wheelock, Mojica, and Singh, 2005; Norwood and Henneberry, 2006; Briggeman, Henneberry and Norwood, 2007). This suggests that non-agriculture degree holders can compete effectively for agriculture industry jobs.

However, other evidence points to firms outside agriculture bidding for the services of agriculture majors. Carnevale, Strohl and Melton (2011) report that 87 percent of college graduates with degrees in agriculture or natural resources have jobs outside agriculture, suggesting that agricultural firms use non-agriculture graduates because agriculture graduates are being lured to other sectors for higher wages, better benefits, or more urban environments. The greater placement of agriculture majors outside agriculture may be a measure of the strength of the curriculum and not a weakness.

We extend the analysis of the returns to agricultural majors by addressing the following questions: 1) What are the returns to agriculture majors compared to other curricula?; 2) Are agriculture majors confined to a narrowing pool of jobs in the agriculture industry or do they find employment outside agriculture?; 3) Are the returns higher inside or outside the agriculture industry?; 4) Are the majors so specific to agriculture that majors' skills are severely discounted outside agriculture?; 5) Does the sorting of agriculture majors inside and outside of the industry correspond to the industry specificity of the major? 
Past studies of returns to agriculture majors have been limited by samples that focused primarily or exclusively on College of Agriculture alumni. These studies confirm the importance of advanced degrees and work experience for higher salaries among these alumni, while documenting a significant but narrowing gender gap (Broder and Deprey, 1985; Preston, Broder, and Almero, 1990; Barkley, 1992; Zekeri, 1992; Barkley, Stock and Sylvius, 1999; Barkley, and Biere, 2001; Qenani-Petrela and McGarry Wolf, 2007). Harris, et al. (2005) find comparable results studying salaries earned by agribusiness management graduates. What these studies do not provide is a comparison to the returns to other college majors.

A handful of studies have examined relative pay in the agriculture industry compared to jobs outside agriculture. Some report an income penalty for alumni in agriculture industry jobs. Zekeri (1992) finds former agriculture students in agriculture-related positions earned roughly 5 percent less than their peers in non-agricultural jobs. Qenani-Petrela and McGarry Wolf (2007) report a 12.4 percent earnings gap between agriculture and other sectors of the economy. Barkley and Biere (2001) find a 33 percent premium for non-agricultural employment relative to agribusiness jobs in a sample of Kansas State University agribusiness and agricultural economics alumni. However earlier studies including all agriculture graduates from Kansas State indicate no salary premium for nonagricultural employment (Barkley, 1992; Barkley, Stock and Sylvius, 1999). Preston et al. (1990) also found no difference in salaries between agriculture and nonagricultural industries for Virginia Tech alumni.

A plausible explanation for the mixed findings regarding the salary discount in agriculture is that ag-related jobs are disproportionately located in rural areas. The rural-urban wage gap is well documented: Kusmin, Gibbs and Parker (2008) report that college graduates earn 23 percent less in nonmetropolitan areas even after controlling for personal characteristics. 
Differences in the ability to control for job location across studies may be one reason for such large discrepancies in measured pay differentials across agriculture and non-agriculture sectors. A second possibility is that some agricultural majors provide more sector-specific training than do others. That suggests that the skills of some agricultural majors will be highly valued in agriculture but discounted heavily in nonagricultural sectors, even as other majors may provide skills that receive a premium in non-agricultural firms.

This study uses a large random sample of graduates of a Midwestern public University to explore the returns by major in the agricultural and non-agricultural sectors. The strength of the study is its ability to identify the value of agricultural sector-specific skills versus general skills developed by major. This data set reflects the incomes of graduates over a 25 -year time period and includes a rich set of controls for academic success within the major, family background, and curricular diversity, increasing the confidence that the results reflect returns to the major and not differences in abilities of individuals across majors. The study has the added advantage that it incorporates the salaries earned by non-agricultural graduates inside and outside the agriculture industry as a reference, and so we gauge earnings of agriculture majors against the universe of all majors in the university.

The results are compelling. Most agriculture majors work outside the agriculture industry. There are substantial returns to agriculture majors working in agriculture, but only when the firms are located in urban areas. Some majors, most notably Animal Science and Agricultural Education and Studies, appear to have substantial sector-specific skills as measured by large pay gaps between jobs inside and outside agriculture. Others, most notably Agricultural Business, earn a wage premium outside agriculture consistent with the development of skills that are broadly valued across sectors. Higher ability graduates in more industry-focused curricula 
tend to sort into the agricultural industry while higher ability graduates in broader curricula tend to choose jobs outside of agriculture. All majors are more likely to accept agricultural employment when the farm economy is strong, but agricultural graduates who enter agricultural jobs when the farm economy is weak suffer lifetime earnings reductions.

\section{Data}

We first establish the stylized facts regarding average earnings by agricultural majors by sector and location. Where possible, we also will show that our results, which are based on a specific university's alumni, are consistent with national data on earnings by agricultural majors.

Our analysis uses a survey of Iowa State University alumni who graduated between 1982 and 2006. Data were collected using a 2007 stratified random sample survey of 25,025 Iowa State University (ISU) alumni graduating between 1982 and 2006 (Jolly, Yu, Orazem, and Kimle 2010). Sample surveys were mailed to 24 percent of the 84,917 alumni who received bachelor's degrees over that period. Respondents could choose to complete the survey on-line or return the questionnaire by mail. We received 5,416 usable surveys for a response rate of 21.6 percent. All reported survey results in this study are weighted to reflect the distribution of graduates by year and college across the universe of almost 85 thousand alumni.

The survey asked respondents a variety of questions about their careers subsequent to graduation in addition to individual demographics and family background. Survey responses were matched to student records containing information about majors, coursework, and extracurricular activities while at ISU. We projected the reported zip codes of alumni's current residency to county FIPS codes and use the Economic Research Service's rural-urban continuum codes (RUCC) to define rural or urban status of their current locations (USDA, ERS, 2004). 
Counties with RUCC 6-9 are defined as rural. The 2003 codes were used to define 2007 rural status

Among alumni working in agricultural industry jobs in 2007, one-third held degrees from a college other than the College of Agriculture and Life Sciences (CALS). Furthermore, among CALS alumni, only 21 percent were employed in agriculture in 2007. Of the jobs in agriculture, 60 percent were located in urban, not rural, areas.

Table 1 reports summary information on salaries earned by agriculture and nonagriculture graduates in agriculture and non-agriculture firms by urban and rural location. On average, non-agriculture majors earn about $\$ 13,000$ more than agriculture majors. In urban areas, there is no significant difference in average income between agriculture and nonagriculture sectors. However, agriculture majors earn a substantial premium over nonagriculture majors in urban agricultural firms, while non-agricultural majors receive a significant premium over agriculture majors in non-agricultural sectors.

The pattern is markedly different in rural markets. Salaries for all majors are over $\$ 18,000$ less in rural markets. Salaries in rural agricultural firms are even lower, averaging $\$ 30,000$ less compared to their urban counterparts. However, there is no premium paid to agriculture majors in rural agriculture firms. Still, non-agricultural majors receive a $\$ 15,000$ premium in rural non-agriculture sectors. Clearly urban versus rural residence is a key factor in assessing the returns to agriculture majors overall and relative to other college majors.

Table 2 displays average earnings in agricultural and non-agricultural industries by more specific groupings of majors within the College of Agriculture and Life Sciences ${ }^{1}$. The range of salaries is remarkable. Within agriculture, the highest average salaries go to Animal Science majors whose pay more than doubles the average in Agricultural Engineering and Plant Science. 
Outside of agriculture, the top salaries in Agriculture Business are more than double those in Agriculture Engineering and Natural Resources.

Equally remarkable differences exist in the probability of being employed in the agriculture industry. Less than 4 percent of Food Science majors work in agriculture, barely more than the proportion of non-agriculture majors. Meanwhile, over one-quarter of Plant Science and Agriculture Engineering majors take jobs in the agriculture sector. Average earnings fall as the fraction employed in agriculture increases with the simple correlation of 0.37 , suggesting that agricultural firms do have trouble competing for college talent at least on average.

There are substantial differences across majors in the average salary paid inside and outside of the agriculture industry. The majors in table 2 are listed in order of the size of the premium paid for working in agriculture. The premium approaches 100 percent in animal science and exceeds 50 percent in Natural Resources. However alumni in other majors earn a premium for working outside agriculture, the largest a 51 percent premium among Agricultural Business majors. Identifying the source of such dramatic variation in returns and employment across majors and sectors is critical for anyone interested in curriculum development or career advising in agriculture.

While this study includes only graduates from one university, our broad statistics correspond with national averages reasonably well. Carnevale, Strohl and Melton (2011) analyzed median earnings and industry of employment for college graduates by major using 2009 American Community Survey data compiled by the U.S. Census. The two samples are not quite comparable as the Census data only included terminal bachelor's degree recipients while the ISU data also includes holders of graduate degrees. Nevertheless, the sample distributions 
for ISU agriculture majors match the universe reasonably well. The main difference is that ISU agriculture graduates are more likely to be employed in the agriculture industry (21 percent versus 13 percent) compared to the universe of agriculture degree recipients. Comparing earnings and employment within more narrowly defined majors (e.g. agricultural economics or plant science) showed a great deal of consistency in relative employment rates in agriculture and in relative pay levels by major. The ISU majors whose relative salaries were higher than those in the national population were the highest ranked agricultural departments at ISU.

\section{Conceptual Framework}

One explanation for differences in returns across industries is that salaries are determined in part by the level of general versus industry-specific human capital an individual possesses. In particular, if salaries are determined in part by firm-specific, industry-specific, or occupationspecific human capital, , then workers incur a penalty when they switch into jobs that do not

require those specific skills (Poletaev and Robinson, 2008) ${ }^{2}$. Skills developed in a college major may also be specific to a particular industry, and so graduates finding employment in other industries will sacrifice their potential returns from major-specific human capital.

We frame our analysis using an adaptation of Neal's (1998) model of training choice. In Neal's two-period model, workers acquire firm-specific training in the first period. In period two, they decide whether to stay in their current position or switch jobs. In our context, individuals choose a major and receive training in college during the first period. Training will have both general and agriculture sector-specific components. In the second period, students graduate and choose employment either in the agriculture industry or in a non-agricultural industry. 
To make this precise, let individual $i$ choose major $j$, where $j=\{A, N\}$. Agriculture majors are indicated by $A$ and non-agriculture majors are indicated by $N$. While in the major, she expects to receive general training skill, $\alpha_{j}$, which is equally valued in all sectors, as well as a major-specific skill, $\delta_{j k}$, which is productive only in sector $k$. Her actual skill level upon completion of the major can deviate from her anticipated skills. In particular, she will discover her suitability to the work related to the major. This is measured by $\varepsilon_{i j}^{C}$, the additional sectorspecific human capital attributable to the quality of the match between her individual abilities, character and interests and the curricular skills required in the major field of work. These match productivities are drawn from an i.i.d. symmetric distribution $G\left(\varepsilon_{i j}^{C}\right)$ with $E\left(\varepsilon_{i j}^{C}\right)=\bar{\varepsilon}$.

In the second period, individuals choose their sector of employment, $k$, where $k=\{A, N\}$. The individual's sectoral income, $Y_{i k}$, reflects both general and sector-specific training. Income for individuals who 'switch' and choose employment in sectors not related to their college major will be fully rewarded for their general skills, but their major-specific skills will be discounted. For ease of exposition, we assume that the major-specific skills that apply to all alumni in the major, $\delta_{j k}$, are fully depreciated outside the major industry, but that the match-specific skills that incorporate individual talents, character, ambition and other personal abilities may retain some value outside the major industry. Match skills specific to major $j$ are discounted in industry $k$ at the rate $\theta_{j}^{k}, \theta_{j}^{k} \in[0,1]$. Those match skills retain all their value in the major industry so that $\theta_{A}^{A}=\theta_{N}^{N}=1$

Let $D_{i j}^{k}$ be a dummy variable equal to 1 if $j=k$ and 0 otherwise. The output price attached to sector-specific productivity is given by $P_{k}$. Accounting for the various sources of skills, income of major $j$ in sector $k$ is:

$$
Y_{i j k}=\alpha_{j}+D_{i j}^{k} P_{k} \delta_{j k}+\theta_{j}^{k} P_{k} \varepsilon_{i j}^{C}
$$


Thus, an agriculture major receives $Y_{i A A}=\alpha_{A}+P_{A} \delta_{A A}+P_{A} \varepsilon_{i A}^{C}$ when working in the agriculture sector, but $Y_{i A A}=\alpha_{A}+\theta_{A}^{N} P_{N} \varepsilon_{i A}^{C}$ working in a non-agriculture sector. Similarly, a non-agriculture major working in agriculture receives $Y_{i N A}=\alpha_{N}+\theta_{N}^{A} P_{A} \varepsilon_{i N}^{C}$, and $Y_{i N N}=\alpha_{N}+$ $P_{N} \delta_{N N}+P_{N} \varepsilon_{i N}^{C}$ when working in a non-agriculture sector.

Risk neutral individuals will pick the sector with the highest earnings such that $Y_{i k}>Y_{i l} \forall k \neq l$. In particular an agriculture major will pick the agriculture sector when $P_{A} \delta_{A A}+P_{A} \varepsilon_{i A}^{C}>\theta_{A}^{N} P_{N} \varepsilon_{i A}^{C}$ or $P_{A} \delta_{A A}+\left(P_{A}-\theta_{A}^{N} P_{N}\right) \varepsilon_{i A}^{C}>0$

Therefore, an agriculture major will opt for the agricultural job when the price of agricultural output is high relative to the nonagricultural sector $\left(P_{A}>P_{N} \geq \theta_{A}^{N} P_{N}\right)$. Alternatively, if prices are higher in the non-agriculture sector $\left(P_{N}>P_{A}\right)$, the agriculture major will still accept employment in the agriculture sector when the return to major-specific skills in the agricultural sector $\left(P_{A} \delta_{A A}\right)$ exceeds the net return from match-specific human capital in the non-agriculture sector, $\left(P_{A}-\theta_{A}^{N} P_{N}\right) \varepsilon_{i A}^{C}$. This is more likely when $\theta_{A}^{N}$ is low, meaning that agriculture major match-specific skills are not easily transferrable to the non-agriculture sector.

The observed return to agriculture majors employed in agriculture relative to nonagriculture will be

$\rho=\left[P_{A} \delta_{A A}+\left(P_{A}-\theta_{A}^{N} P_{N}\right) \varepsilon_{i A}^{C}\right] \mid\left[\left(P_{A} \delta_{A A}+\left(P_{A}-\theta_{A}^{N} P_{N}\right) \varepsilon_{i A}^{C}\right)>0\right]$

This is the average gain from picking the agricultural sector relative to the non-agriculture sector for those majors who select the agriculture sector. In experimental terms, this is the treatment effect on the treated where the treatment is obtaining employment in the agriculture industry. Importantly, this will differ from the value of sector-specific training for the population as a whole because of nonrandom sorting across sectors. In particular, as illustrated in figure 1, the 
observed and population returns will only be identical when $\rho=P_{A} \delta_{A A}$, i.e. when the expected match capital for those in the agricultural jobs, $E\left(\varepsilon_{i j}^{C}\right)=\bar{\varepsilon}=0$. When the expectation is nonzero, the observed return will depend on the sign of the relative output prices in the agriculture and nonagriculture sectors and on the degree to which match-specific capital is discounted in the nonagricultural jobs, and the estimated $\rho$ will reflect the incentives to sort into or out of agricultural jobs.

To see this, note that when $\left(P_{A}-\theta_{A}^{N} P_{N}\right)>0$, those sorting into the agriculture sector will have atypically large match capital draws, and so $E\left(\varepsilon_{i A}^{C} \mid\left(P_{A}-\theta_{A}^{N} P_{N}\right)>0\right)=\overline{\varepsilon_{A}^{+}}>\bar{\varepsilon}>0$. In markets when agricultural prices are atypically strong, or in majors whose skills are heavily discounted outside agriculture, those picking agriculture jobs will be drawn from the upper tail of the distribution of match-specific skills. Their observed returns in agriculture will be larger than the returns that would have been observed had everyone in that major selected a job in agriculture. However, when $\left(P_{A}-\theta_{A}^{N} P_{N}\right)<0$ so that nonagricultural prices are high or agriculture match-specific skills retain their value outside agriculture, graduates with the largest match-specific skills will be better off taking nonagricultural jobs. The expected match-specific capital for the majors taking agriculture jobs will be $E\left(\varepsilon_{i A}^{C} \mid\left(P_{A}-\theta_{A}^{N} P_{N}\right)<0\right)=\overline{\varepsilon_{A}^{-}}<\bar{\varepsilon}$. Consequently, estimated returns to selecting an agricultural job will understate the expected returns for the population of majors as a whole in markets when agricultural prices are weak or where major-specific skills are not heavily discounted in nonmajor jobs.

A key implication of figure 1 is that the best students in a given agriculture major will not necessarily take jobs in agriculture. We can test this expectation indirectly by looking at sorting by grade point average, presuming that both observed and unobserved major-specific skills are positively correlated with academic performance in the major. Agriculture majors employed in 
agriculture had average GPAs of 3.04 compared to 2.96 for those employed in other sectors. While the difference is statistically significant, it is numerically small. In 3 of 8 majors, average GPA is higher for those taking jobs outside agriculture. We will examine later whether the sorting into and out of agriculture jobs appears consistent with our estimates of major-specific human capital.

Thus far, our analysis has treated the general skills $\alpha_{i}$ as identical across sectors so that sector choice is unrelated to the general component of skills. If $\alpha_{i}$ is correlated with the unobserved sector-specific skills, then our measure of $\rho$ will be subject to an additional source of selection bias associated with nonrandom sorting across sectors on general skills. To allow variation in general skills by sector, we parameterize the general training measure by $\alpha_{i}=X_{i}^{\prime} \beta$ where $X_{i}$ is a vector of human capital measures reflecting academic performance, family background and socio-economic status, and work experience since leaving college. To the extent that the sorting across sectors is attributable to these observable factors across sectors, inclusion of $X_{i}$ as a proxy for general skills will correct for nonrandom sorting on ability.

\section{Empirical Specification}

The empirical specification follows from equation (1). Our dependent variable, $\ln \left(Y_{i j k}\right)$, is the natural $\log$ of the 2007 salary of ISU alumni $i$ in major $j$ and sector $k$. The survey instrument collected salary information using categorical variables. ${ }^{3}$ For this analysis, we use the midpoint of each category to approximate actual salary. 


$$
\begin{gathered}
\ln \left(Y_{i j k}\right)=\left(\alpha_{N}+P_{N}\left(\delta_{N N}+\varepsilon_{i N}^{C}\right)\right)+X^{\prime}{ }_{i} \beta+D_{i N}^{A}\left(-P_{N} \delta_{N N}+\left(\theta_{N}^{A} P_{A}-P_{N}\right) \varepsilon_{i N}^{C}\right)+ \\
D_{i A}^{A}\left(-\alpha_{N}-P_{N}\left(\delta_{N N}+\varepsilon_{i N}^{C}\right)+\alpha_{A}+P_{A}\left(\delta_{A A}+\varepsilon_{i A}^{C}\right)\right)+ \\
D_{i A}^{N}\left(-\alpha_{N}-P_{N}\left(\delta_{N N}+\varepsilon_{i N}^{C}\right)+\alpha_{A}+\theta_{A}^{N} P_{N} \varepsilon_{i A}^{C}\right)+\xi_{i j k}
\end{gathered}
$$

where $\xi_{i j k}$ is assumed to be a random error uncorrelated with observed background attributes, $X_{i}$, choice of major or sector of employment. In our application of (4), we further subdivide the agriculture degree dummy variables into $D_{i A j}^{A}$ and $D_{i A j}^{N} ; j=1, \ldots 8$, where the 8 subgroups are the 8 agriculture majors listed in table 2 . We also estimate a variant of (4) with separate returns for urban and rural residents to examine whether the major-specific skills differ in value across urban and rural markets. ${ }^{4}$ In the urban-rural variant, we only report results for a single aggregated agriculture major because thin samples led to unreasonable estimates for some majors in rural markets.

In our estimation of specification (4), the sector specific prices, $\mathrm{P}_{\mathrm{N}}$ and $\mathrm{P}_{\mathrm{A}}$ become part of the coefficient. We relax this restriction later by building in interactions with an index of net farm income to measure the relative strength of the agriculture industry compared to other sectors at the time of graduation. The reason we focus on income rather than just price is because relative productivity as well as relative price may change over time, and both will affect the relative value of time in and out of agriculture. ${ }^{5}$

The vector of human capital measures, $X_{i}$, includes measures of college experience, post baccalaureate education and career experiences, demographic and family background variables. College experience variables. These measures control for breadth of the curriculum and academic success. Variables include cumulative grade point average, length of time in school, whether the alumni had a double major, and the degree of specialization in the major. ${ }^{6}$ 
Career variables. Post-baccalaureate career experience measures include the number of years since earning the first bachelor's degree (experience), whether the alumnus/alumna holds a graduate degree, the number of jobs held since graduation, whether the individual has ever started a for-profit business, and current employment status (full-time or part-time and whether self-employed or not). A term interacting gender with part-time work is also included to control for likely differences in work experience related to the length of the part-time spell by gender (Corcoran, Duncan and Ponza, 1983) ${ }^{7}$.

Demographic and family background variables. We include race and gender as explanatory variables in addition to a set of family-related variables. These include father's education, number of siblings, whether the individual's family operated a farm business or other type of business and the individual's high school rank. We also include a series of dummy variables controlling for year of graduation and, in specification (4), rural residence.

\section{Regression Results}

Table 3 presents the estimates of the observed differences in earnings between the agricultural and non-agricultural sectors $(\rho)$ by major and location, conditional on the vector of observable human capital $X_{i}$. We report the main parameters of interest to conserve space. Complete regression results are provided in appendix tables A4 and A5. The signs of the additional controls are generally as expected and consistent with previous studies.

Applying specification (4) separately by urban and rural location, Panel A provides the estimated returns by major, industry and resdience relative to a base salary for nonagricultural majors employed outside agriculture in urban markets. All reported coefficients are converted into percentage differences from the base salary. ${ }^{8}$ Returns to an agriculture major are highest in urban markets with a 24 percent urban salary premium in agriculture jobs and a 10 percent urban 
salary premium in non-agriculture jobs. Even larger urban premia are found for non-agriculture majors.

The estimated major-specific human capital in agriculture, $\rho$, is $15.9 \%$ in urban markets. The estimated $\rho$ in rural markets is only $2 \%$ and is not statistically significant. For nonagriculture majors, major-specific human capital applies to jobs outside agriculture. The estimated $\rho$ for non-agriculture majors is $6 \%$ in urban markets and $11.5 \%$ in rural markets. Clearly on average, there is a wage premium paid for getting a job more closely aligned with the major, but the range of $2-16 \%$ suggests that the premium is surprisingly small.

Further insights follow from applying specification (4) allowing for separate impacts by agriculture major. Panel B provides the key estimates relative to the base category, a nonagricultural degree in a non-agricultural job. As before, positive values of $\rho$ imply higher returns in agriculture than in nonagriculture jobs, while negative values imply higher wages for the major outside of agriculture. In 6 of 8 agriculture majors, $\rho$ is positive. Of these, three are statistically significant suggesting the existence of major-specific human capital: Animal Science, Other Agriculture ${ }^{9}$ and Agricultural Education and Studies. The two agriculture majors with negative and significant estimated $\rho$ are Agricultural Business and Food/Biological Science, meaning that majors earn more in nonagricultural jobs. The 6.4 percent premium earned by Agricultural Economics/Agribusiness majors outside agriculture is consistent with, albeit smaller than, the 33 percent premium reported for Agribusiness majors at Kansas State (Barkley and Biere, 2001). Non-agriculture majors earn $8.4 \%$ more in nonagricultural jobs, suggesting a modest sized but statistically significant level of major-specific human capital in nonagriculture majors. 
The literal interpretation of these estimates is that agriculture degrees commanding a sizeable premium in the agriculture industry such as Animal Science or Agricultural Education and Studies focus their curricula on material that only earns a return in agriculture jobs. However, the majority of degree recipients in those majors work outside agriculture and are penalized for their more specialized training. In contrast, the Agricultural Economics/Agribusiness degree has a greater emphasis on general skills that are valued both inside and outside of agriculture. To illustrate the magnitude of the estimated penalty or premium from degree-industry match, we compute the predicted salary across majors and industries for a given alumnus: a white, male, 1985 graduate, non-entrepreneur working full-time in an urban location, with average values for the remaining family background, college experience and career measures. Table 4 displays these results sorted in ascending order according to the size of the premium for working in agriculture. An Agricultural Economics/Agribusiness major would earn about $\$ 5,000$ a year less working in rather than out of agriculture. Almost the same gap is found for non-agriculture majors. On the other hand, an Animal Science major earns roughly $\$ 23,000$ per year more in an agriculture job than outside agriculture. The annual salary gaps favoring agriculture jobs are $\$ 12,000$ for an Agricultural Education and Studies major and $\$ 11,000$ for Other Agriculture majors. These gaps are not small. Over a 40 year work career, the present value of earning $\$ 11,000$ per year is almost $\$ 200,000$ at a $5 \%$ discount rate.

\section{Business Cycle Effects}

As we illustrated with figure 1 , the observed $\rho$ will vary with the relative strengths of the agriculture and nonagriculture labor markets. Past studies have already shown that graduating into a recessed labor market causes long-term reductions in returns to college (Khan, 2010). The 
returns to majors that focus narrowly on skills required for one sector would be particularly vulnerable if the recession atypically affected the targeted job sector. In the case of agriculture, the 1982 recession resulted in sharp reductions in farmland prices and the failure or forced consolidation of rural banks, dragging out the farm recovery in Iowa and other Midwest states for several years after the national economy had rebounded. In contrast, the 1992 recession barely affected Iowa and was followed by the longest expansion in the history of the United States. The 2001 recession mainly affected the national non-agricultural market for college graduates.

Armed with historical information on the relative strength of the agriculture and nonagriculture sectors, we can explore how stronger or weaker market conditions affected the earnings for the various majors. One approach is to add cohort effects into the earnings function. We divide our alumni into 3 cohorts $C_{l}$ : 1982-1986 (agricultural recession but expansion outside agriculture); $C_{2}$ : 1987-2001 (a period of general economic expansion across both sectors); and $C_{3}:$ 2002-2006 (a period of weak job growth outside agriculture but strong demand for agriculture products). By interacting these cohort dummy variables with major and sector of employment, we can assess whether major-specific returns in agricultural and non-agricultural sectors vary across sector-specific business cycles. In addition, we expect that majors with the largest sector-specific human capital, $\rho$, would be hurt most when they graduated into a recessed agricultural market but should have been hurt less in recessions that hit non-agricultural sectors more. The specification used to investigate these hypotheses is

$$
\begin{gathered}
\ln \left(Y_{i j t}^{k}\right)=\alpha_{0}+\left(\alpha_{N 1}+\delta_{N N 1}\right)+X_{i}^{\prime} \beta+\sum_{t=2}^{3} C_{i t} D_{i N t}^{N}\left(-\alpha_{N 1}-\delta_{N N 1}+\alpha_{N t}+\delta_{N N t}\right)+ \\
\sum_{t=1}^{3} C_{i t} D_{i N t}^{A}\left(-\delta_{N N t}\right)+\sum_{t=1}^{3} C_{i t} D_{i A t}^{A}\left(-\alpha_{N 1}-\delta_{N N 1}+\alpha_{A t}+\delta_{A A t}\right)+
\end{gathered}
$$




$$
\begin{aligned}
& \sum_{t=1}^{3} C_{i t} D_{i A t}^{N}\left(-\alpha_{N 1}-\delta_{N N 1}+\alpha_{A t}\right)+\sum_{t=1}^{3} \gamma_{N t} C_{i t}\left(D_{i A t}^{N}+D_{i N t}^{N}\right) \widehat{\rho}_{J}+ \\
& \sum_{t=1}^{3} \gamma_{A t} C_{i t}\left(D_{i A t}^{A}+D_{i N t}^{A}\right) \widehat{\rho}_{\jmath}+\xi_{i j k t} .
\end{aligned}
$$

In this formulation, we use the estimated $\rho_{j}$ in table 3 as an estimate of the degree to which the major specializes in skills unique to the agriculture industry. The more specialized agriculture majors are those in table 3 with positive estimates of $\rho_{j}$, while more general agriculture majors, Food Science and Agricultural Economics/Agribusiness, as well as non-agriculture majors, have negative estimates of $\rho_{j}$. Using the returns to non-agriculture majors in non-agricultural jobs in period $1\left(\alpha_{N 1}+P_{N}\left(\delta_{N N 1}+\varepsilon_{i N 1}^{C}\right)\right)$ as the frame of reference, we can show how returns to the agriculture and non-agriculture majors changed across the three time periods. We can then use the estimates of $\gamma_{N t}$ and $\gamma_{A t}$ to show how more or less specialization in agriculture affected returns in the non-agriculture and agriculture sectors, respectively.

Table 5 reports our findings. Non-agricultural degree holders from the 1982-1986 graduation cohort working in the agriculture industry earned about 35 percent less than their peers working outside of agriculture. Agriculture majors graduating during this period had higher earnings if they took jobs outside agriculture, as they earned 19 percent less than nonagriculture majors in nonagriculture jobs, but 19 percent more than agriculture majors working in agriculture. More specialized agriculture majors who found jobs in agriculture gained 1.9 percent higher earnings for every percentage increase in $\rho$, but those more specialized majors who took the more plentiful jobs outside agriculture in that era lost 0.7 percent in earnings for every percentage increase in $\rho$.

Alumni graduating with agriculture degrees during the national expansionary period between 1987 and 2001 earned 444 percent more working in agriculture jobs than did the 198286 agriculture graduates. However, non-agriculture majors earned much more on average, even 
when working in the agriculture sector. The 20 percent premium over base earned by nonagriculture majors in agriculture jobs is even larger than the 5.5 percent premium earned by agriculture majors. The return from specialization in the agriculture sector is half that in the 1982-86 period at 0.9 percent increased earnings per percent increase in $\rho$. Working outside agriculture still penalized more specialized agriculture training.

For the 2002-2006 cohort, returns to an agriculture degree are much better than in the earlier periods and dominate returns to a non-agriculture degree in the agricultural sector. However, the estimated return to specialization actually turns negative in both sectors. This suggests that recent graduates with more specialized majors incurred an earnings penalty even when working in agriculture, while graduates of the more general agricultural programs earned a premium both in agricultural jobs and in jobs outside agriculture. A plausible explanation for the rising value of general skills is offered by Lazear's (2005) "Jack-of-all-Trades" model of entrepreneurship. He shows theoretically and empirically that firm owners are broadly trained while their employees are specialists. If the labor market is increasingly valuing managerial skills involving decisions spanning many academic disciplines, then we would expect to find rising relative returns to majors offering broader training (Orazem, Yu, and Jolly, 2010).

An alternative specification which more explicitly incorporates a measure of sectorspecific prices interacts our continuous measure of net farm income with major and sector of employment. Complete regressions results are available in appendix table A6. To illustrate the magnitude of the estimated penalty or premium from graduating in a recessed economy, we use the same approach applied in table 4 . We compute the predicted salary for a given alumnus: a white, male, 1985 alumnus, non-entrepreneur working full-time in an urban location, with average values for the remaining family background, college experience and career measures, 
but vary the market conditions at the time of graduation. In particular, we chose the best (2006) and worst (1985) years for farm income included in the time frame of our data. We compare the effect of specialization by comparing the results for an alumnus holding the most specialized agriculture degree, Animal Science, with the more general degree, Agricultural Economics/Agribusiness. These results are reported in table 6.

Graduating into a recessed agriculture market has large, long-term effects on earnings of agriculture majors regardless of sector or employment. Evaluated at 22 years of job experience, simulated annual earnings for graduates of more general agriculture majors are $\$ 16$ thousand less in the agriculture sector and $\$ 60$ thousand less outside agriculture than an identical alumnus graduating in a strong farm economy year. For more specialized majors, the annual penalty from graduating into a weak farm economy is $\$ 35$ thousand in agriculture and $\$ 51$ thousand outside agriculture.

Our finding of large costs to graduating in a recession are in line with recent studies of large earnings loss associated with recessions. Khan (2010) found that a man who graduated in December 1982 when the unemployment rate was $10.2 \%$ earned $23 \%$ less than an observationally equivalent graduate entering the labor market 18 months earlier when the economy was at full employment. The earnings disadvantages compared to graduates in normal times persisted and were still between 4-5\% 12 years after graduation. For a typical worker, lost earnings from graduating in a bust market were on the order of $\$ 100,000$ less over 18 years. Similar costs of recessions are reported by Davis and von Wachter (2011) who found that the present value of lost earnings from job loss in a recession cost $19 \%$ compared to workers who retain jobs.

\section{Non-Random Sorting into Agriculture Industry Jobs}


We can now return to the issue of nonrandom sorting by agriculture majors into jobs into and outside agriculture. Our theoretical model predicts that an individual's incentive to choose a job in agriculture increases when the level of major-specific skills $\left(\delta_{A A}\right)$ is large; when relative prices for agricultural commodities are high; when match-specific capital $\left(\varepsilon_{i A}^{C}\right)$ is large; and when match-specific capital is discounted more heavily in the nonagricultural jobs $\left(\theta_{A}^{N}\right)$. Furthermore, the upper-tail of the skill distribution of a major will sort atypically into agricultural jobs when the major has a high value of $\theta_{A}^{N}$. Although we do not observe $\delta_{A A}, \theta_{A}^{N}$, or $\varepsilon_{i A}^{C}$ directly, our estimate of $\rho$ represents a combination of these effects such that $\frac{\partial \rho}{\partial \delta_{A A}}>0, \frac{\partial \rho}{\partial \theta_{A}^{N}}>0$, and $\frac{\partial \rho}{\partial \varepsilon_{i A}^{C}}>0$. Consequently, we can test indirectly for the sorting effects by examining how job choices are affected by $\rho$.

The hypotheses regarding $\operatorname{Pr}(A A)$ : the probability an agriculture major selects agricultural employment are:

1) The probability of selecting agricultural employment rises with the level of majorspecific human capital: $\frac{\partial \operatorname{Pr}(A A)}{\partial \rho}>0$.

2) The probability of selecting agricultural employment rises with relative agriculture prices, $\frac{\partial \operatorname{Pr}(A A)}{\partial P_{A}}>0$.

3) Assuming that grade point average $(G P A)$ is a legitimate measure of match-specific skill in a major, $\varepsilon_{i A}^{C}$, then the probability of selecting agricultural employment rises with $G P A$ in markets with a higher level of major-specific human capital: $\frac{\partial \operatorname{Pr}(A A)}{\partial \rho} \frac{\partial \rho}{\partial G P A}>0$.

Table 7 displays these results, which are consistent with our expectations. Majors with higher levels of $\rho$ are more likely to have employment in the agricultural industry and higher ability (higher GPA) students in these more specialized majors are more likely to be employed in 
agriculture. We observe a positive effect of a strong farm economy on the probability of having an agriculture job.

\section{Conclusions and Implications}

This paper examines the relative returns to an agricultural degree from working in or outside of the agricultural industry. We find most agricultural majors are employed in non-agricultural industries. Furthermore, we find sizeable differences in earnings across majors from working in agriculture. Agricultural Economics/Agribusiness majors actually earn significantly more in non-agriculture fields, suggesting that this major develops more generally-valued skills, while graduates of Animal Science and Agricultural Education and Studies programs earn large premiums working in agriculture. These differences in relative wages inside and outside agriculture are consistent with a model that assumes earnings depend on general skills learned in college and on major-specific human capital.

We also find large negative effects on earnings for alumni graduating during economic downturns. The negative cohort effects for more specialized agriculture majors graduating during the 1980s agriculture recession suggests that having a narrowly focused major may be risky in that it makes it more difficult to adjust to changing economic circumstances. Significant shifts in industry dynamics, apart from economic distress, may also represent a risk to having a more narrowly focused major.

Patterns of sorting into and out of agricultural jobs by success in the major are consistent with our findings of relative returns to major-specific capital and the quality of the match between individuals' unobserved abilities and the skills required in the major. The higher ability graduates of majors more narrowly focused on the agriculture industry tend to take jobs in agriculture while higher ability graduates in broader curricula tend to choose jobs outside of 
agriculture. However, the majority of graduates across all agricultural majors, narrow and broad, take jobs outside of agriculture. That suggests that broader curricula that will not be as heavily discounted outside of agriculture would benefit the majority of future graduates.

A referee challenged us to explain how the results of our examination of earnings could more concretely guide curricular reform. The most likely research strategy would be to modify the approach used by Poletaev and Robinson (2008). They examined the earnings changes of workers reemployed following a job loss due to plant closings or large layoffs. For each worker, they defined the old and new job as a collection of skill requirements. They found that the larger the change in required skills from old to new job, the greater the earnings loss. One could similarly decompose majors into a vector of required general and applied skills. One could then examine how those skills are rewarded inside and outside agriculture. Skills that are heavily discounted outside agriculture are major-specific and majors that heavily weight those skills may want to explore adding additional weight to skills that are more highly rewarded outside agriculture. To our knowledge, this exercise has never been done for any set of college majors, but our findings suggest that much could be learned from the exercise.

Returns to development of specialized skills and knowledge while obtaining an undergraduate degree vary considerably. While teaching more specialized, industry-specific knowledge and skills can reward the minority of students who land jobs in agriculture, it can hurt the majority of majors who find work in other sectors. Our findings support the current momentum toward developing more general skills in agricultural majors that will not be as heavily discounted outside of agriculture such as communication and business skills (Larson 1996). In fact, this paper shows that there are inherent risks in specialization of undergraduate 
studies, whether those risks arise from career changes, sector-specific changes or shocks, or economic circumstances. 


\section{Endnotes}

${ }^{1}$ See appendix table A1 for specific degree programs included in each major category.

${ }^{2}$ In this analysis we presume the specificity resides at the industry or sector level (rather than the firm or occupation level).

${ }^{3}$ The survey brackets for personal income are: Less than $\$ 25,000 ; \$ 25,000$ to $\$ 39,999 ; \$ 40,000$ to $\$ 59,999 ; \$ 60,000$ to $\$ 74,999 ; \$ 75,000$ to $\$ 99,999 ; \$ 100,000$ to $\$ 149,999 ; \$ 150,000$ to $\$ 249,999 ; \$ 250,000$ to $\$ 500,000$; and More than $\$ 500,000$.

${ }^{4}$ As is common with earnings functions, we are treating schooling decisions, in this case choice of one of 9 majors, as exogenous as well as the decisions regarding urban or rural location or sector of employment. As a practical matter, it is not feasible to develop sufficient credible instruments to identify major, location, and sector choices. The literature on returns to schooling has shown that various methods used to correct for potential endogeneity of schooling decisions results in estimated returns to schooling that are broadly consistent with least-squares estimates (Card, 1999).

${ }^{5}$ The relative value of time working in agriculture versus other sectors changes over time due both to changes in relative prices and to changes in relative productivity across the two sectors. Our measure of net farm income is a combination of both relative price and productivity and thus a measure of relative profitability of the agricultural sector at the time of graduation.

${ }^{6}$ This measure developed by Lazear (2005) is constructed as the credits taken in the major minus the largest number of credits earned in a department outside the major.

${ }^{7}$ Incidence of part-time employment as a fraction of all employed for workers over 20 is $25 \%$ for women but only $11 \%$ of men. U.S. Bureau of Labor Statistics: http://www.bls.gov/web/empsit/cpseea06.htm 
${ }^{8}$ With the log-linear regression specification, the percentage change in personal income resulting from a categorical variable is $g^{*}=\exp \left(\beta_{k}-0.5 \sigma_{k}^{2}\right)-1$ (Kennedy, 1981), $\beta_{k}$ is the estimated coefficient for the $k t h$ dummy variable and $\sigma_{k}^{2}$ is the variance of $\beta_{k}$.

${ }^{9}$ The Other Agriculture category includes Public Service and Administration in Agriculture, Agricultural Journalism, Sociology and Professional Agriculture majors. 


\section{Works Cited}

Barkley, A. P. 1992. "Earnings of Kansas State University Agriculture Graduates: 1978-88." American Journal of Agricultural Economics 74: 215-222.

Barkley, A.P., W.A. Stock, and C. K. Sylvius. 1999. "Agricultural Graduate Earnings: The Impacts of College, Career, and Gender." American Journal of Agricultural Economics 81:785-800.

Barkley, A. and A. Biere. 2001. "Does undergraduate major matter? Differences in salaries and satisfaction levels of Agribusiness and Agricultural Economics majors at Kansas State University." International Food and Agribusiness Management Review 4:167-187.

Boland, M. and J. Akridge. 2004. “Undergraduate Agribusiness Programs: Focus or Falter?” Review of Agricultural Economics 26:564-578.

Briggeman, B., S.R. Henneberry and F.B. Norwood. 2007. "How Do Employers Assess Job Candidate Attributes?" NACTA Journal (Sept.): 15-21.

Broder, J. M. and R. P. Deprey. 1985. "Monetary Returns to Bachelors and Masters Degrees in Agricultural Economics." American Journal of Agricultural Economics 67:666-673.

Card, D. (1999), "The causal effect of education on earnings," in O. Ashenfelter and D. Card, eds. Handbook of Labor Economics Vol 3A (Elsevier Science B.V.,Amsterdam).

Carnevale, A.P., J. Strohl and M.Melton. 2011. "What's It Worth: The Economic Value of College Majors." Center on Education and the Workforce. Georgetown University. http://cew.georgetown.edu/whatsitworth/Accessed 25 May 2011.

Corcoran, M. G. J. Duncan and M. Ponza. 1983. A Longitudinal Analysis of White Women's Wages. The Journal of Human Resources 18(4):497-520.

Davis, S. and T. von Wachter. 2011. "Recession and the Costs of Job Loss" Brookings Papers on Economic Activity, forthcoming. 
Economic Research Service (ERS), U.S. Department of Agriculture (USDA). 2004. Rural-Urban Continuum Codes. http://www.ers.usda.gov/Data/RuralUrbanContinuumCodes/

Goodman, R. M. 1992. "The challenges for professional education in agriculture: A corporate vantage point.” In K.G. Brandt, et al. (Eds.), Agriculture and the undergraduate. Washington, DC: Board on Agriculture, National Research Council, National Academy Press, pp. 41-50.

Harris, K., D. Sanders, S. Gress and N. Kuhns. 2005. "Starting Salaries for Agribusiness Graduates From an AASCARR Institution: The Case of Southern Illinois University." Agribusiness 21(1): $65-80$.

Jolly, R., L. Yu, P. Orazem, K. Kimle. 2010. Entrepreneurship and Higher Education: An Overview of the Iowa State University Alumni Survey. (Working Paper \# 10003). Ames, IA: Department of Economics, Iowa State University.

Kennedy, P. 1981. "Estimation with Correctly Interpreted Dummy Variables in Semilogarithmic Equations." The American Economic Review 71(4): 801.

Khan, L. B. 2010. "The long-term labor market consequences of graduating from college in a bad economy." Labour Economics 17:303-316.

Kusmin, L., R. Gibbs \& T. Parker. 2008. "Education's role in the metro-nonmetro earnings divide." Amber Waves 6(1): 30-35.

Larson, Ronald, B. 1996. “Agricultural Business Management Curricula.”Journal of Agribusiness. 14-2 (Fall 1996): 143-155.

Lazear, Edward. "Entrepreneurship." Journal of Labor Economics 23(4) 2005: 649-680.

Levine, A. S. 2012. "Yahoo's 'College Majors That Are Useless'... Really?" The Huffington Post, January 20. http://www.huffingtonpost.com/allen-s-levine/useless-college-majors_b_1217401.html

Loose, T. 2012. "College Majors That Are Useless," Yahoo!Education, January. http://education.yahoo.net/articles/most_useless_degrees.htm. 
Neal, D. 1998. "The Link between Ability and Specialization: An Explanation for Observed Correlations between Wages and Mobility Rates." Journal of Human Resources 33(1):173-200.

Norwood, F.B. and S.R. Henneberry. 2006. "Show me the Money: The Value of College Graduate Attributes as Expressed by Employers and Perceived by Students." Amer. J. Agr. Econ. 88 : 484 498.

Onianwa, O., G. Wheelock, M. Mojica, and S. Singh. 2005. "Agribusiness Firms in Alabama: Profiles and Perceptions of Skills and Experiences Needed for Careers in Agribusiness." Journal of Food Distribution Research 36(1): 124-129.

Orazem, P., L. Yu and R. Jolly. (2010) “Bachelor's degrees and business start-ups: A reexamination of Lazear's Theory of Entrepreneurship." Iowa State University Working Paper.

Poletaev M. and C. Robinson. 2008. "Human Capital Specificity: Evidence from the Dictionary of Occupational Titles and Displace Workers Surveys, 1984-2000." Journal of Labor Economics 26(3): $387-420$.

Preston, W.P., J. M. Broder, M.C.P. Almero. 1990. "Temporal Analysis of Income Earned by Former Agriculture Students." American Journal of Agricultural Economics 72,:13-23.

Qenani-Petrela, E. and M McGarry Wolf . 2007. "Differential Earnings of the Agricultural Graduates New Evidence from the Agribusiness Industry." International Food and Agribusiness Management Review 10(2):49-66.

U.S. Bureau of Labor Statistics. 2012. Labor Force Statistics from the Current Population Survey. http://www.bls.gov/web/empsit/cpseea06.htm

Zekeri. J. 1992. "Income Attainment among Land Grant colleges of Agriculture Alumni." Journal of Vocational Behavior 41:200-206. 
Figure 1: The effect of nonrandom sorting into the agricultural sector on average unobserved sectorspecific human capital

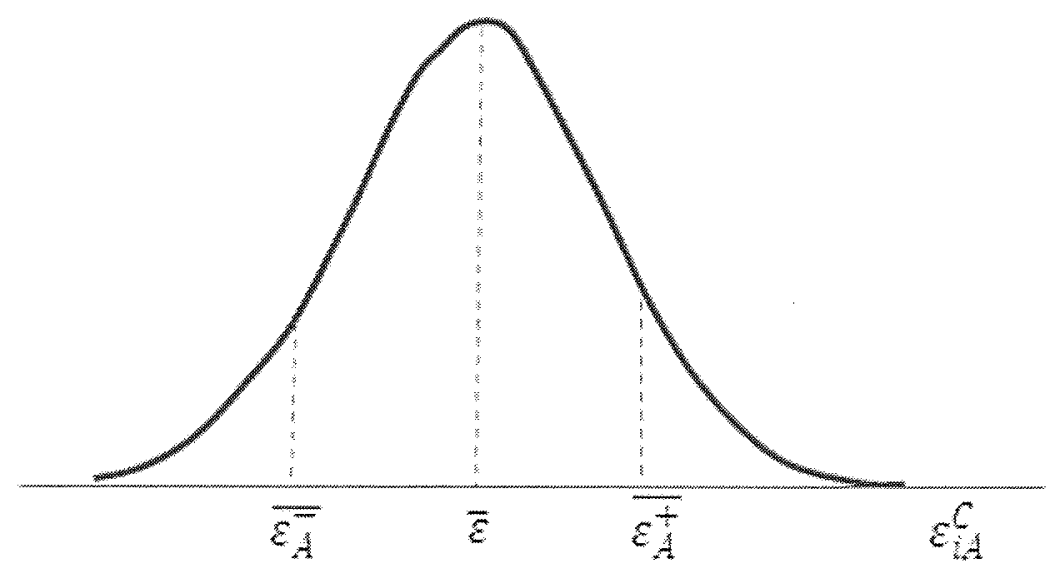

Notes: is the agricultural sector-specific human capital that results from the quality of the match between individual abilities and skills developed in a given agricultural major. is the mean level of in the population of graduates in that major. the conditional mean of for those selecting an agricultural job in a major whose skills are discounted heavily in nonagricultural jobs. is the conditional mean of in a major whose skills retain much of their value in nonagricultural jobs. 


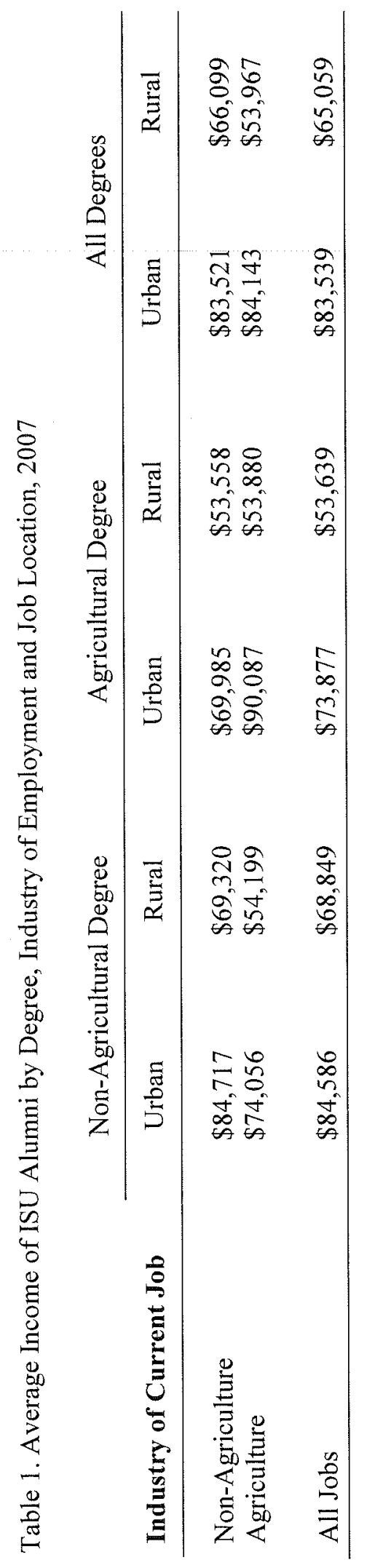




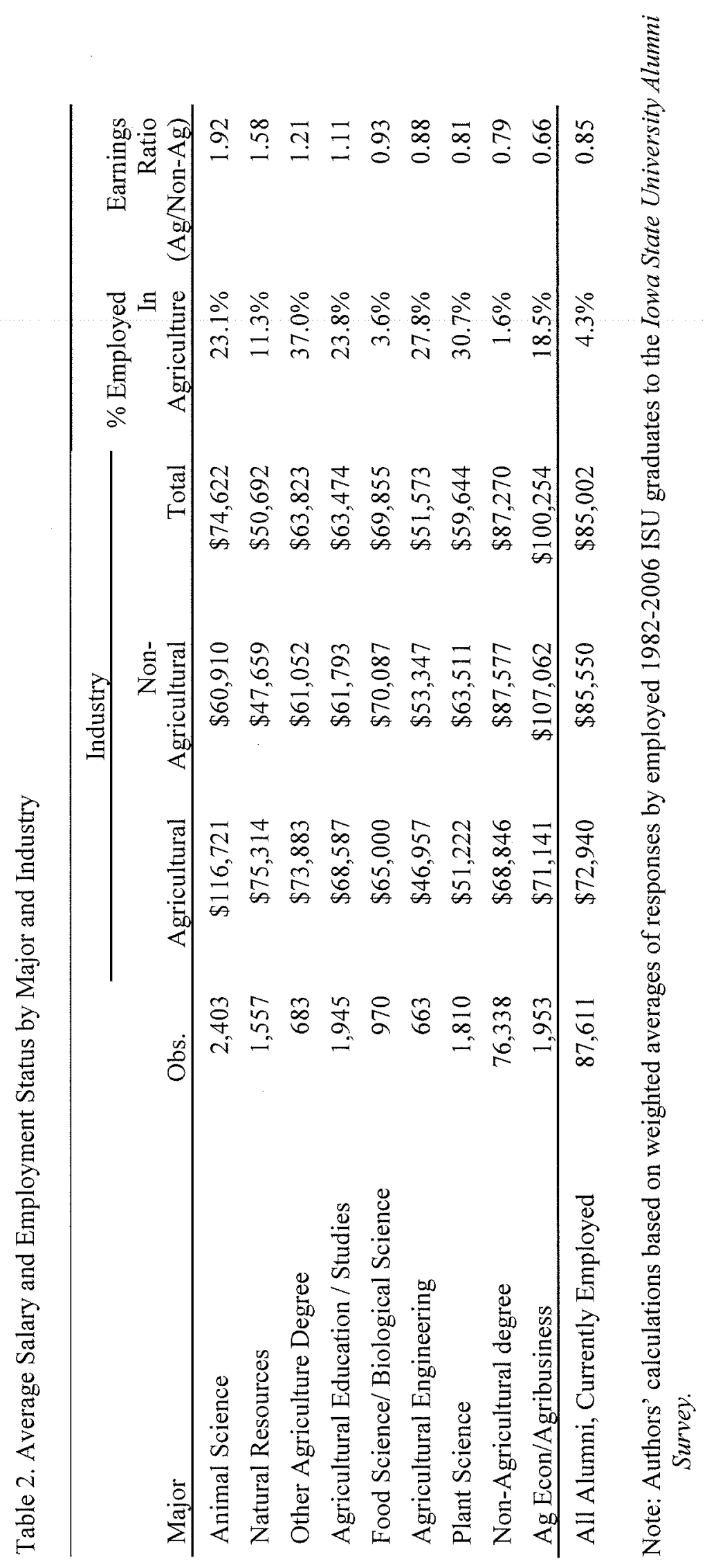


Table 3. Estimated Percent Difference in Income by Major and Industry of Employment

\begin{tabular}{|c|c|c|c|c|c|}
\hline & & & stry & & \\
\hline Major & & Agricultural & $\begin{array}{c}\text { Non- } \\
\text { Agricultural } \\
\end{array}$ & $\rho$ & $\begin{array}{l}\text { Across Industry } \\
(\text { prob }>\text { F) }\end{array}$ \\
\hline A: College \& Location & & & & & \\
\hline Non-Agricultural degree & Urban & $\begin{array}{l}-6.0^{* * *} \\
(3.02)\end{array}$ & -- base & $-6.0^{\mathrm{a}}$ & $0.003^{* *}$ \\
\hline & Rural & $\begin{array}{c}-31.4 * * * \\
(12.81)\end{array}$ & $\begin{array}{c}-19.8 * * * \\
(38.36)\end{array}$ & $-11.5^{\mathrm{a}}$ & $0.000 * * *$ \\
\hline Agricultural degree & Urban & $\begin{array}{c}-1.6 \\
(1.00)\end{array}$ & $\begin{array}{c}-17.5 * * * \\
(23.28)\end{array}$ & 15.9 & $0.000 * * *$ \\
\hline & Rural & $\begin{array}{c}-25.4^{* * *} \\
(15.99)\end{array}$ & $\begin{array}{c}-27.5 * * * \\
(29.30)\end{array}$ & 2.0 & 0.175 \\
\hline B: Detailed Major & & & & & \\
\hline Non-Agricultural degree & & $\begin{array}{c}-8.4 * * * \\
(5.23)\end{array}$ & -- base & $-8.4^{\mathrm{a}}$ & $0.000^{* * *}$ \\
\hline Food/Biological Science & & $\begin{array}{c}-29.5 * * * \\
(3.764)\end{array}$ & $\begin{array}{c}-16.5 * * * \\
(8.60)\end{array}$ & -13.0 & $0.089^{*}$ \\
\hline Natural Resources & & $\begin{array}{c}-23.8 * * * \\
(6.83)\end{array}$ & $\begin{array}{c}-30.7^{* * *} \\
(22.02)\end{array}$ & 3.9 & 0.248 \\
\hline Ag Econ/Agribusiness & & $\begin{array}{c}2.3 \\
(0.75)\end{array}$ & $\begin{array}{l}8.7 * * * \\
(5.52)\end{array}$ & -6.4 & $0.068^{*}$ \\
\hline Animal Science & & $\begin{array}{c}16.7 * * * \\
(6.41)\end{array}$ & $\begin{array}{c}-15.8 * * * \\
(12.200)\end{array}$ & 32.6 & $0.000 * * *$ \\
\hline Agricultural Education /St & dies & $\begin{array}{c}-1.4 \\
(0.491)\end{array}$ & $\begin{array}{c}-15.2 * * * \\
(10.35)\end{array}$ & 13.8 & $0.000 * * *$ \\
\hline Agricultural Engineering & & $\begin{array}{c}-20.2 * * * \\
(5.14)\end{array}$ & $\begin{array}{c}-27.9 * * * \\
(10.62)\end{array}$ & 4.2 & 0.286 \\
\hline Plant Science & & $\begin{array}{c}-19.1 * * * \\
(8.23)\end{array}$ & $\begin{array}{c}-20.4 * * * \\
(13.35)\end{array}$ & 1.3 & 0.583 \\
\hline Other Agriculture & & & & & \\
\hline Degree & & $\begin{array}{c}25.4^{* * *} \\
(4.99) \\
\end{array}$ & $\begin{array}{c}7.4^{* *} \\
(2.52) \\
\end{array}$ & 18.0 & $0.004 * * *$ \\
\hline $\begin{array}{l}\text { Note: Complete regression res } \\
\text { family background, economic } \\
\text { denote significance at the } 10 \mathrm{p} \\
\text { a The measure of major-specifi } \\
\text { the estimate as the implied loss } \\
\text { to be consistent with the estim }\end{array}$ & $\begin{array}{l}\text { s are rep } \\
\text { nditions, } \\
\text { tent }(*) \text {, } \\
\text { luman c }\end{array}$ & $\begin{array}{l}\text { ted in appendix } \\
\text { emographics an } \\
\text { sercent }\left({ }^{* *}\right) \text { an } \\
\text { tal for non-ag }\end{array}$ & $\begin{array}{l}\text { e A5 and inclu } \\
\text { reer experience } \\
\text { ercent }(* * *) \text { le } \\
\text { rs in the non-as } \\
\text { or who accept }\end{array}$ & $\begin{array}{l}\text { ols for } \\
\text { stics in } \\
\text { re secto } \\
\text { ment in }\end{array}$ & $\begin{array}{l}\text { idual ability, } \\
\text { theses. Asterisks } \\
\text { 6.0. We report } \\
\text { griculture sector }\end{array}$ \\
\hline
\end{tabular}


Table 4. Estimated Salary of Sample Alumnus by Major and Industry

\begin{tabular}{lccr} 
& \multicolumn{3}{c}{ Industry } \\
\cline { 2 - 3 } Major & Agriculture & Non-Agriculture & Difference \\
\cline { 2 - 3 } Food \& Biological Sciences & $\$ 51,696$ & $\$ 60,110$ & $-\$ 8,414$ \\
Non-Agriculture & $\$ 68,352$ & $\$ 73,845$ & $-\$ 5,493$ \\
Ag Econ/Agribusiness & $\$ 75,066$ & $\$ 80,196$ & $-\$ 5,130$ \\
Plant Science & $\$ 59,960$ & $\$ 58,696$ & $\$ 1,264$ \\
Ag Engineering & $\$ 60,514$ & $\$ 57,184$ & $\$ 3,330$ \\
Natural Resources & $\$ 56,361$ & $\$ 50,535$ & $\$ 5,825$ \\
Other Agriculture & $\$ 92,266$ & $\$ 81,546$ & $\$ 10,719$ \\
Ag Education/Ag Studies & $\$ 74,4610$ & $\$ 62,413$ & $\$ 12,048$ \\
Animal Science & $\$ 85,061$ & $\$ 62,046$ & $\$ 23,016$ \\
\hline $\begin{array}{l}\text { Note: Salaries predicted across majors and industries for a given alumnus using regression results in appendix table } \\
\text { A5. Alumni assumed to be a white, male, } 1985 \text { alumnus, non-entrepreneur working full-time in an urban location, } \\
\text { with average values for the remaining family background, college experience and career measures. }\end{array}$
\end{tabular}




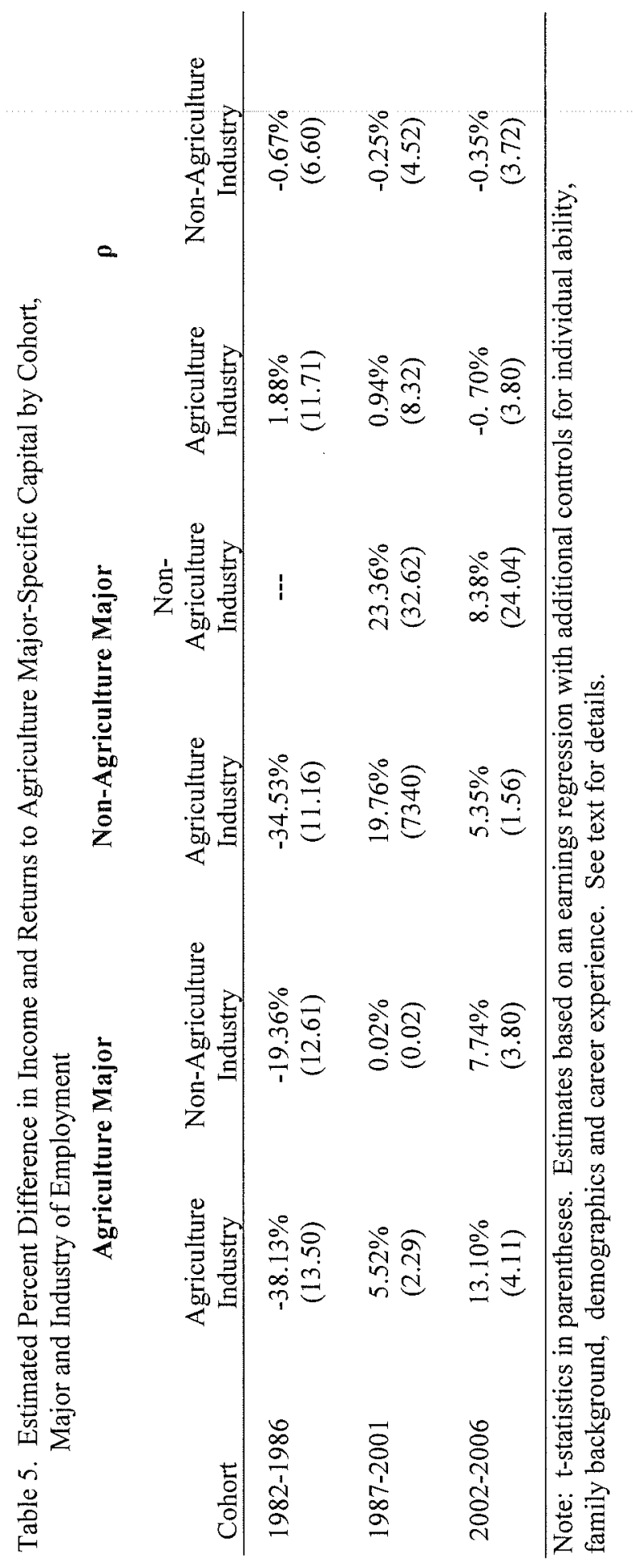




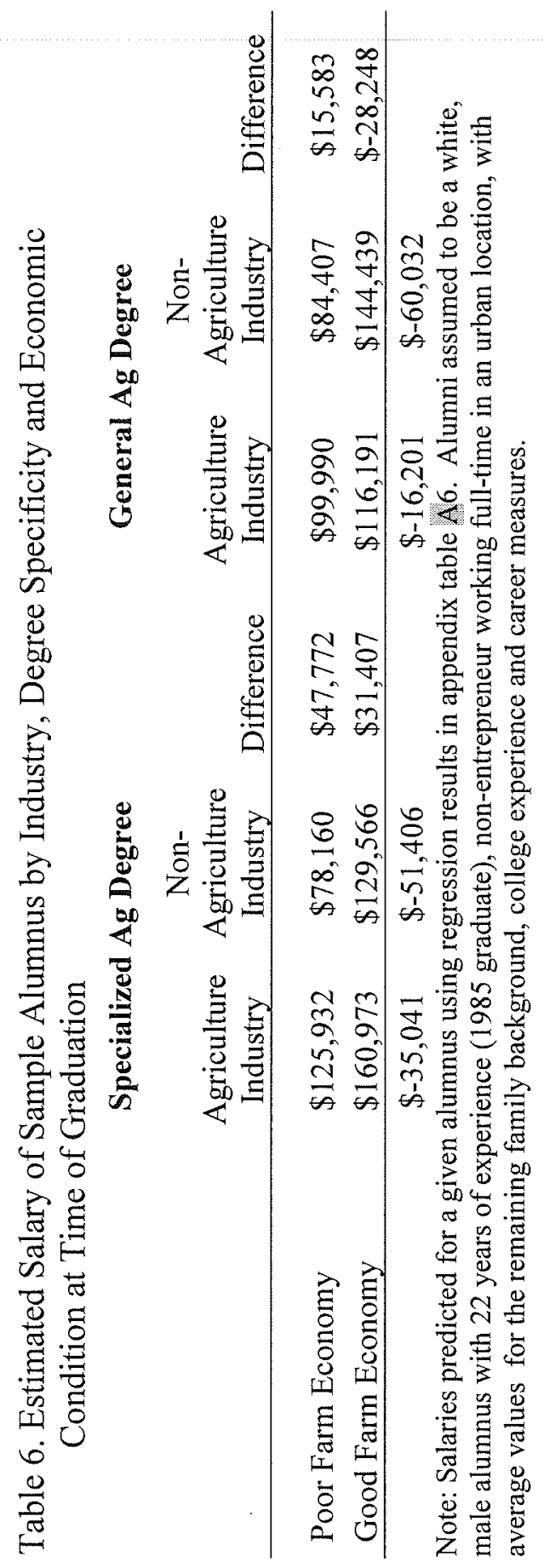




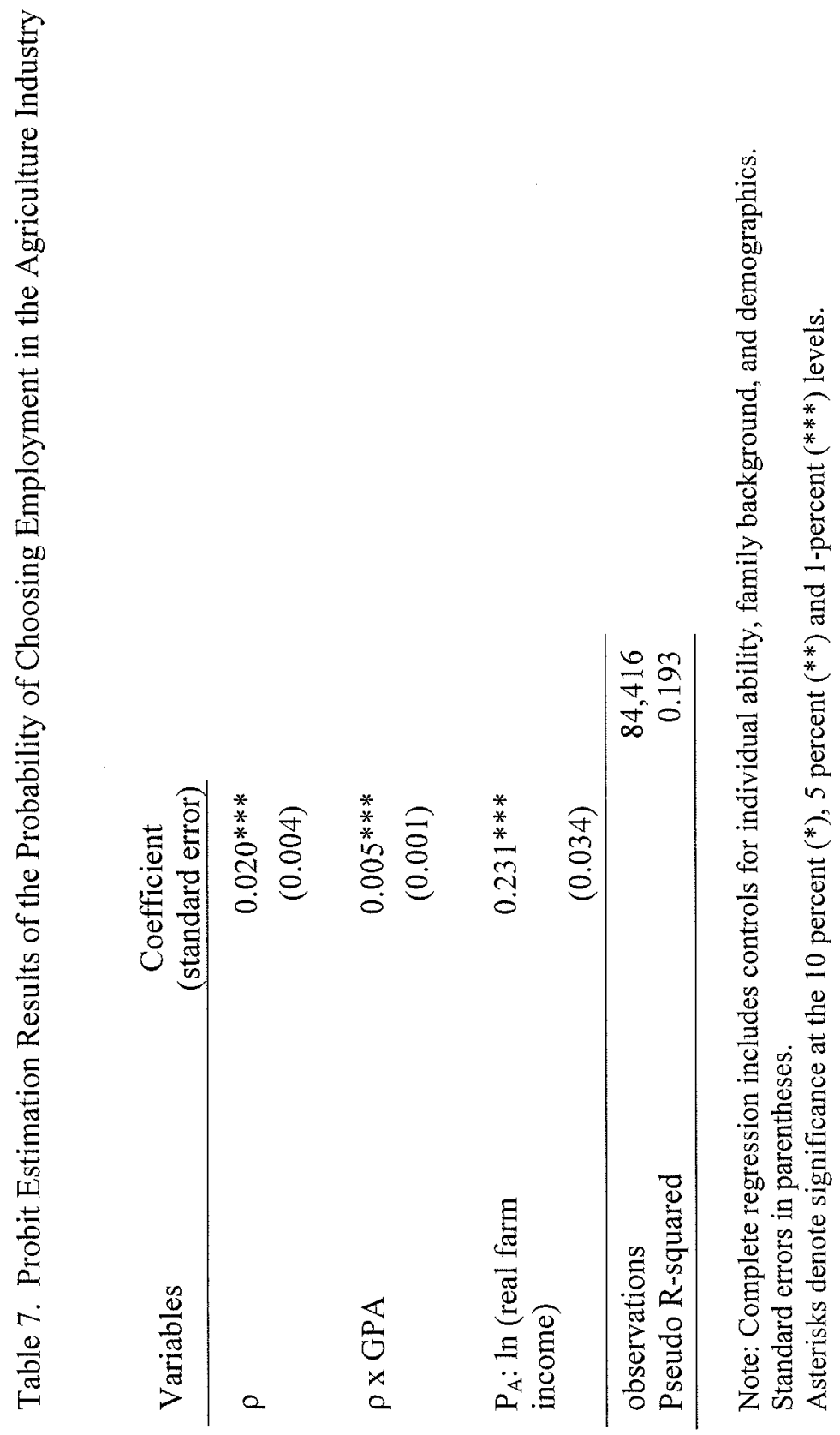




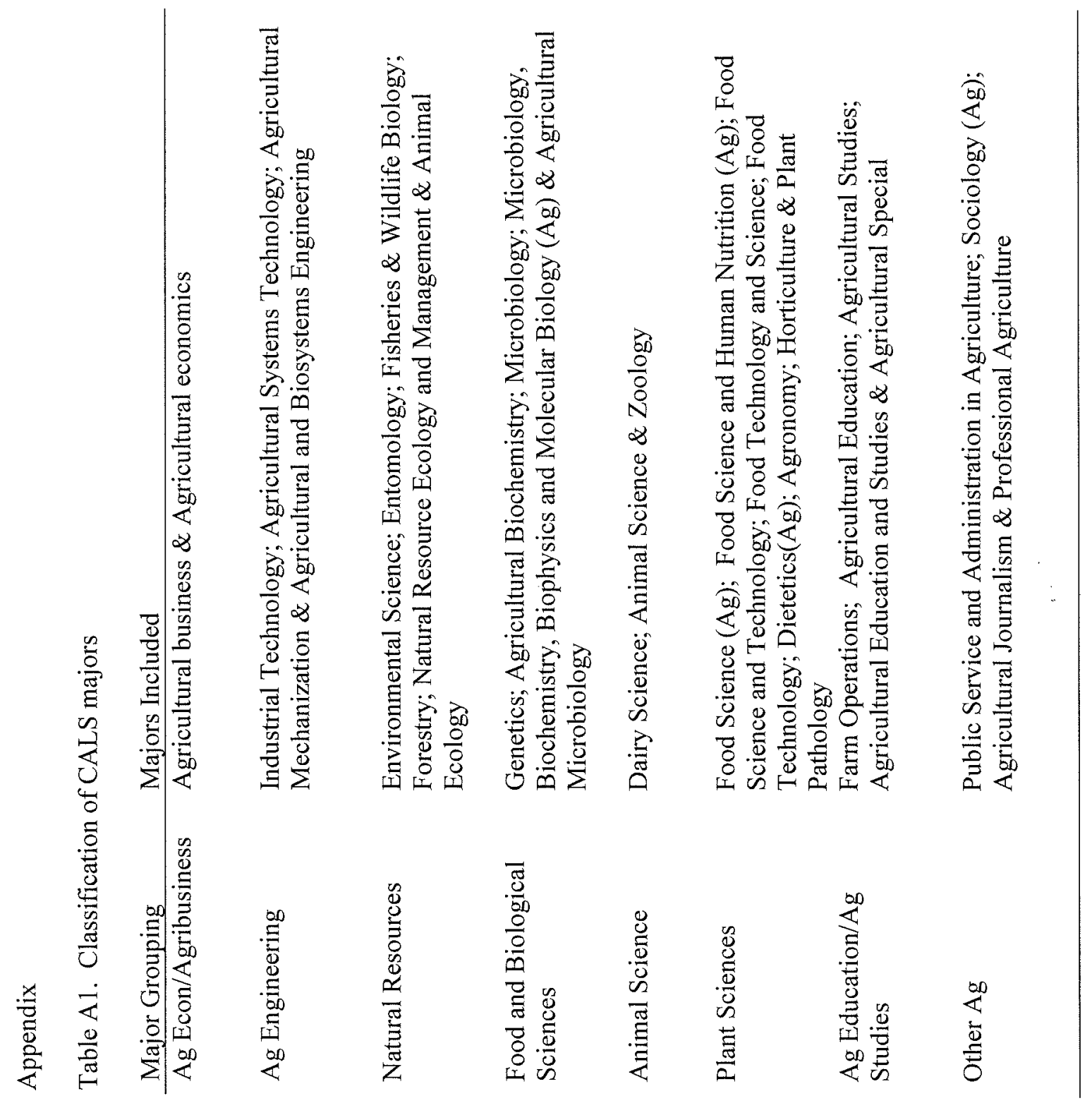




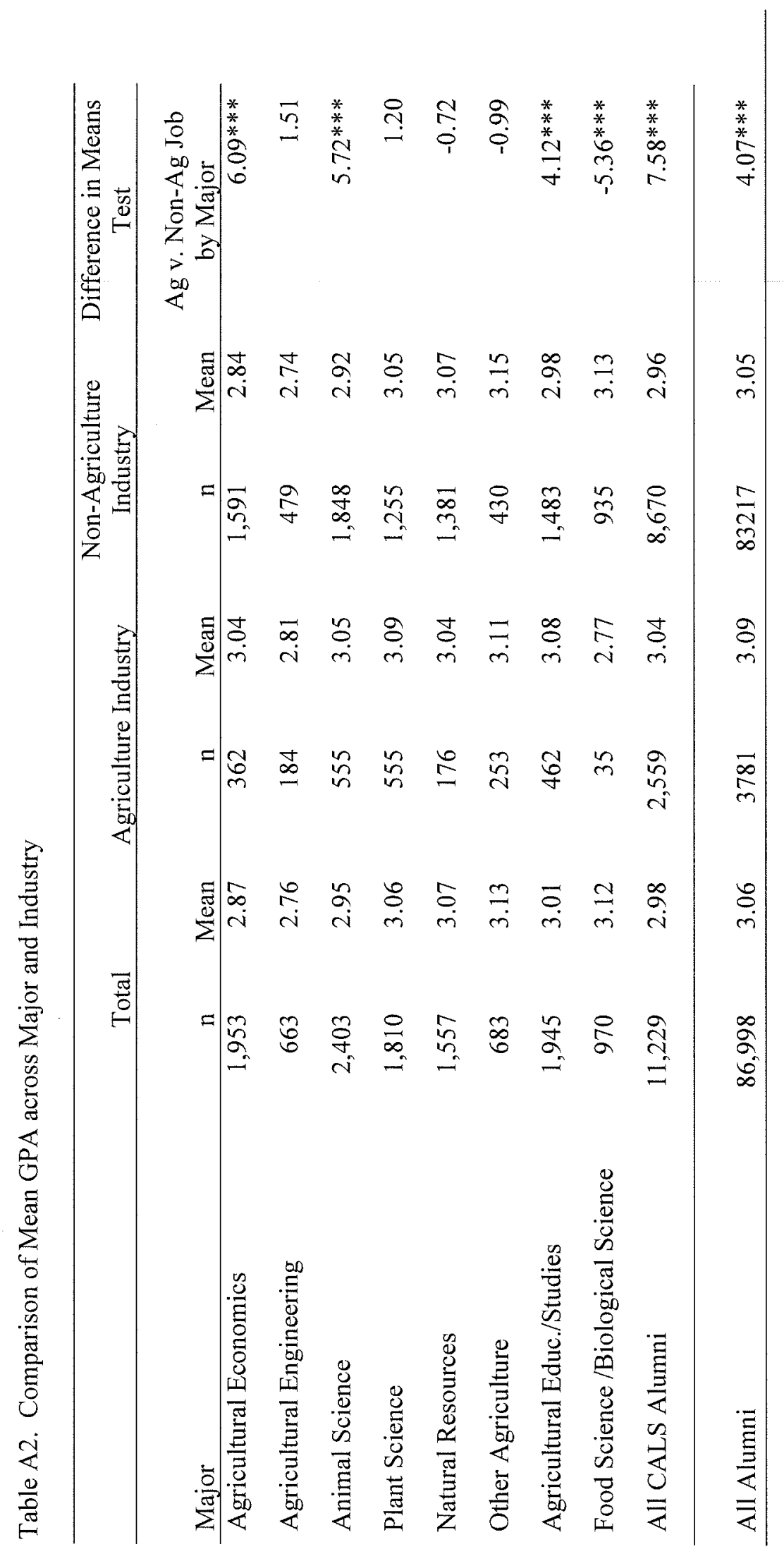




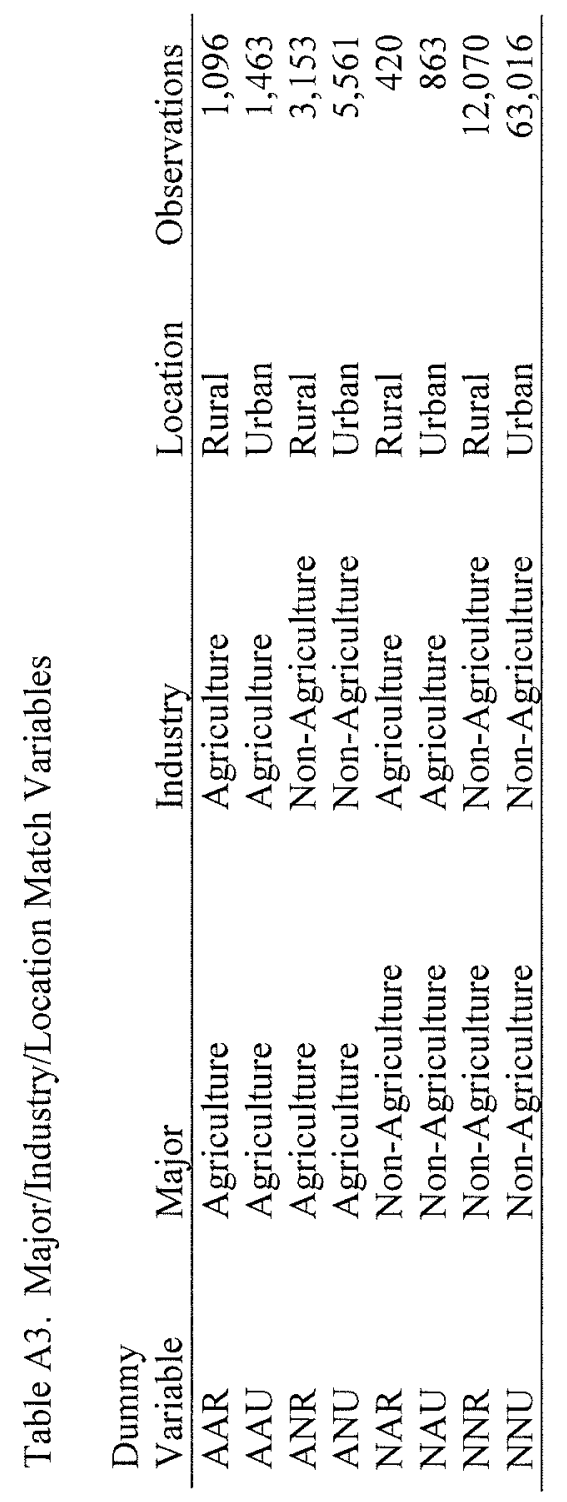


Table A4. ISU Alumni Salary Regression Results

\begin{tabular}{|c|c|c|c|}
\hline Variable & Est. Coefficient & t-stat & Est. $\% \Delta$ \\
\hline Constant (NNU) & $3.252 * * *$ & $(53.13)$ & \\
\hline AAR & $-0.273^{* * *}$ & $(15.00)$ & $-23.9 \%$ \\
\hline AAU & -0.022 & $(1.43)$ & $-2.2 \%$ \\
\hline ANR & $-0.319 * * *$ & $(29.31)$ & $-27.3 \%$ \\
\hline ANU & $-0.198 * * *$ & $(24.14)$ & $-17.9 \%$ \\
\hline NAR & $-0.374 * * *$ & $(12.83)$ & $-31.2 \%$ \\
\hline NAU & $-0.048 * *$ & $(2.435)$ & $-4.7 \%$ \\
\hline NNR & $-0.222 * * *$ & $(38.74)$ & $-19.9 \%$ \\
\hline \multicolumn{4}{|l|}{ Individual Characteristics } \\
\hline Male & $0.343 * * *$ & $(78.83)$ & $32.8 \%$ \\
\hline Black & $-0.063 * *$ & $(4.09)$ & $-6.1 \%$ \\
\hline Asian & $0.195 * * *$ & (11.73) & $21.5 \%$ \\
\hline Native American & $-0.240 * * *$ & $(3.98)$ & $-21.4 \%$ \\
\hline Hispanic & 0.022 & $(1.11)$ & $2.2 \%$ \\
\hline Race unknown & $-0.107 * * *$ & $(5.52)$ & $-10.2 \%$ \\
\hline \multicolumn{4}{|l|}{ Family \& HS background } \\
\hline Father's education & $0.021 * * *$ & $(17.27)$ & $2.1 \%$ \\
\hline Number siblings & $-0.007 * * *$ & $(5.61)$ & $-0.7 \%$ \\
\hline Farm business & $0.024^{* *}$ & $(3.57)$ & $2.4 \%$ \\
\hline Parent business & $0.053 * * *$ & $(11.96)$ & $5.4 \%$ \\
\hline High School Rank & $0.001 * * *$ & $(11.93)$ & $0.1 \%$ \\
\hline \multicolumn{4}{|l|}{ ISU curriculum } \\
\hline GPA & $0.058 * * *$ & $(14.75)$ & $5.8 \%$ \\
\hline Specialization & $-0.007 * * *$ & $(23.40)$ & $-0.7 \%$ \\
\hline Length in school & $-0.037^{* * *}$ & $(8.16)$ & $-3.7 \%$ \\
\hline Double major & $0.033^{* * *}$ & $(3.94)$ & $3.3 \%$ \\
\hline $1987-1991$ & $0.247^{* * *}$ & $(26.12)$ & $28.1 \%$ \\
\hline 1992-1996 & $0.302^{* * *}$ & $(20.09)$ & $35.3 \%$ \\
\hline $1997-2001$ & $0.324 * * *$ & $(15.301)$ & $38.3 \%$ \\
\hline $2002-2006$ & $0.2658^{* * *}$ & $(9.15)$ & $39.5 \%$ \\
\hline \multicolumn{4}{|c|}{ Post Baccalaureate Measures } \\
\hline Experience & $0.047 * * *$ & $(32.08)$ & $4.7 \%$ \\
\hline Graduate degree & $0.132 * * *$ & $(31.97)$ & $14.1 \%$ \\
\hline Number of jobs & $-0.022 * * *$ & $(26.81)$ & $-2.2 \%$ \\
\hline Entrepreneur & $0.048^{* * *}$ & $(7.75)$ & $4.9 \%$ \\
\hline Employed part-time & $-0.650 * * *$ & $(49.89)$ & $-47.8 \%$ \\
\hline Self-Employed full time & $-0.076^{* * *}$ & $(7.789)$ & $-7.4 \%$ \\
\hline Self-Employed part time & $-0.372 * * *$ & $(26.72)$ & $-31.1 \%$ \\
\hline Woman*part time & $-0.295^{* * *}$ & $(20.65)$ & $-25.6 \%$ \\
\hline $\ln$ (Farm Income) & $-0.036^{* * *}$ & $(3.18)$ & $-3.6 \%$ \\
\hline $\begin{array}{l}\text { observations } \\
\text { R-squared }\end{array}$ & $\begin{array}{r}83000 \\
0.4181\end{array}$ & & \\
\hline
\end{tabular}


Table A5. ISU Alumni Salary Regression Results with Detailed Major Categories

\begin{tabular}{|c|c|c|c|}
\hline Variable & Est. Coefficient & t-stat & Est. $\% \Delta$ \\
\hline Constant & $2.781 * * *$ & $(65.63)$ & \\
\hline Non-Ag Degree, Ag Job & $-0.0787^{* * *}$ & $(5.23)$ & $-8.4 \%$ \\
\hline Ag Economics, Ag Job & 0.023 & $(0.75)$ & $2.3 \%$ \\
\hline Ag Economics, Non-Ag Job & $0.083^{* * *}$ & $(5.52)$ & $8.7 \%$ \\
\hline Ag Engineering, Ag Job & $-0.225^{* * *}$ & $(5.14)$ & $-20.2 \%$ \\
\hline Ag Engineering, Non-Ag Job & $-0.279 * * *$ & $(10.62)$ & $-24.4 \%$ \\
\hline Animal Science, Ag Job & $0.155^{* * *}$ & $(6.41)$ & $16.7 \%$ \\
\hline Animal Science, Non-Ag Job & $-0.172 * * *$ & $(12.00)$ & $-15.8 \%$ \\
\hline Plant Science, Ag Job & $-0.212 * * *$ & $(8.23)$ & $-19.1 \%$ \\
\hline Plant Science, Non-Ag Job & $-0.229 * * *$ & (13.35) & $-20.4 \%$ \\
\hline Natural Resources, Ag Job & $-0.310^{* * *}$ & $(6.83)$ & $-26.8 \%$ \\
\hline Natural Resources, Non-Ag Job & $-0.3676^{* *}$ & $(22.03)$ & $-30.7 \%$ \\
\hline Other Ag, Ag Job & $0.227^{* * *}$ & $(4.98)$ & $25.4 \%$ \\
\hline Other Ag, Non-Ag Job & $0.072^{* *}$ & $(2.52)$ & $7.4 \%$ \\
\hline Ag Educ, Ag Job & -0.0139 & $(0.49)$ & $-1.4 \%$ \\
\hline Ag Educ, Non-Ag Job & $-0.164^{* * *}$ & $(10.35)$ & $-15.2 \%$ \\
\hline Food/Bio. Sci, Ag Job & $-0.345^{* * *}$ & $(3.64)$ & $-29.5 \%$ \\
\hline Food/Bio. Sci, Non-Ag Job & $-0.185 * * *$ & $(8.60)$ & $-16.5 \%$ \\
\hline \multicolumn{4}{|l|}{ Individual Characteristics } \\
\hline Male & $0.351^{* * *}$ & $(80.0)$ & $42.0 \%$ \\
\hline Black & $-0.041^{* *}$ & $(2.69)$ & $-4.1 \%$ \\
\hline Asian & $0.195^{* *}$ & $(11.71)$ & $21.5 \%$ \\
\hline Native American & $-0.248 * * *$ & $(4.08)$ & $-22.1 \%$ \\
\hline Hispanic & 0.023 & $(1.15)$ & $2.3 \%$ \\
\hline Race unknown & $-0.133^{* * *}$ & $(6.78)$ & $-12.4 \%$ \\
\hline \multicolumn{4}{|l|}{ Family \& HS background } \\
\hline Father's education & $0.021 * * *$ & $(17.29)$ & $2.1 \%$ \\
\hline Number siblings & $-0.011^{* * *}$ & $(8.89)$ & $-1.1 \%$ \\
\hline Farm business & -0.001 & $(0.20)$ & $0.1 \%$ \\
\hline Parent business & $0.052^{* * *}$ & $(11.69)$ & $5.3 \%$ \\
\hline High School Rank & $0.001 * * *$ & $(8.77)$ & $0.1 \%$ \\
\hline \multicolumn{4}{|l|}{ ISU curriculum } \\
\hline GPA & $0.068 * * *$ & $(17.38)$ & $6.8 \%$ \\
\hline Specialization & $-0.007^{* * *}$ & $(24.23)$ & $-0.7 \%$ \\
\hline Length in school & $-0.031 * * *$ & $(6.92)$ & $-3.1 \%$ \\
\hline Double major & $0.008^{* * *}$ & $(0.98)$ & $0.8 \%$ \\
\hline
\end{tabular}


Post Baccalaureate Measures

Experience

Graduate degree

Number of jobs

Entrepreneur

Employed part-time

Self-Employed full time

Self-Employed part time

Woman*part time

Rural

$\ln$ (Farm Income)

observations

R-squared

\begin{tabular}{rrr}
$0.039^{* * *}$ & $(103.40)$ & $3.9 \%$ \\
$0.1328^{* * *}$ & $(31.73)$ & $14.1 \%$ \\
$-0.019^{* * *}$ & $(23.31)$ & $-1.9 \%$ \\
$0.035^{* * *}$ & $(5.71)$ & $3.6 \%$ \\
$-0.676^{* * *}$ & $(51.66)$ & $-49.1 \%$ \\
$-0.059^{* * *}$ & $(6.11)$ & $-5.8 \%$ \\
$-0.372^{* * *}$ & $(26.60)$ & $-31.1 \%$ \\
$-0.280^{* * *}$ & $(19.40)$ & $-24.4 \%$ \\
$-0.209^{* * *}$ & $(40.69)$ & $-18.9 \%$ \\
\hline $0.161^{* * *}$ & $(17.43)$ & $-1.6 \%$
\end{tabular}

83000

0.411 
Table A6. ISU Alumni Salary Regression Results with Net Farm Income Interactions

\begin{tabular}{|c|c|c|c|}
\hline Variable & Est. Coefficient & t-stat & Est. $\% \Delta$ \\
\hline Constant (NN) & $2.919 * *$ & $(66.71)$ & \\
\hline Ag Degree, Ag Job (AA) & -0.563 & $(0.30)$ & $-7.2 \%$ \\
\hline Ag Degree, Non-Ag Job (AN) & $-1.126 * * *$ & $(11.99)$ & $-67.7 \%$ \\
\hline Non-Ag Degree, Ag Job (NA) & $-1.721^{* * *}$ & $(7.02)$ & $-82.6 \%$ \\
\hline $\mathrm{AA} * \ln ($ farm income $)$ & $0.110^{* *}$ & $(2.30)$ & $11.5 \%$ \\
\hline $\mathrm{AN} * \ln ($ farm income $)$ & $0.376^{* * *}$ & $(16.09)$ & $45.6 \%$ \\
\hline $\mathrm{NA} * \ln ($ farm income $)$ & $0.537^{* * *}$ & $(8.71)$ & $70.7 \%$ \\
\hline $\mathrm{NN} * \ln ($ farm income $)$ & $0.125^{* * *}$ & $(12.91)$ & $13.4 \%$ \\
\hline $\mathrm{AA} * \ln (\text { farm income })^{*} \mathrm{p}_{\mathrm{i}}$ & $0.002 * * *$ & $(9.15)$ & $0.19 \%$ \\
\hline $\mathrm{AN} * \ln ($ farm income $) * \rho_{\mathrm{i}}$ & $-0.001^{* * *}$ & $(6.09)$ & $-0.06 \%$ \\
\hline \multicolumn{4}{|l|}{ Individual Characteristics } \\
\hline Male & $0.351 * * *$ & $(80.26)$ & $42.1 \%$ \\
\hline Black & $-0.035^{* *}$ & $(-2.28)$ & $-3.5 \%$ \\
\hline Asian & $0.202 * *$ & $(12.09)$ & $22.4 \%$ \\
\hline Native American & $-0.212 * * *$ & $(3.49)$ & $-19.3 \%$ \\
\hline Hispanic & 0.028 & $(1.44)$ & $2.9 \%$ \\
\hline Race unknown & $-0.113 * * *$ & $(5.79)$ & $-10.7 \%$ \\
\hline \multicolumn{4}{|l|}{ Family \& HS background } \\
\hline Father's education & $0.021^{* * *}$ & $(17.18)$ & $2.1 \%$ \\
\hline Number siblings & $-0.001 * * *$ & $(7.46)$ & $-0.1 \%$ \\
\hline Farm business & $0.018 * * *$ & $(2.76)$ & $1.8 \%$ \\
\hline Parent business & $0.054^{* * *}$ & $(12.11)$ & $5.6 \%$ \\
\hline High School Rank & $0.001 * * *$ & $(8.94)$ & $0.1 \%$ \\
\hline \multicolumn{4}{|l|}{ ISU curriculum } \\
\hline GPA & $0.067^{* * *}$ & $(17.11)$ & $6.7 \%$ \\
\hline Specialization & $-0.007 * * *$ & $(25.55)$ & $-0.7 \%$ \\
\hline Length in school & $-0.030 * * *$ & $(6.71)$ & $-3.0 \%$ \\
\hline Double major & 0.013 & $(1.56)$ & $1.3 \%$ \\
\hline \multicolumn{4}{|l|}{ Post Baccalaureate Measures } \\
\hline Experience & $0.039 * * *$ & $(103.14)$ & $3.9 \%$ \\
\hline Graduate degree & $0.134^{* * *}$ & $(32.29)$ & $14.4 \%$ \\
\hline Number of jobs & $-0.019 * * *$ & $(23.31)$ & $-1.9 \%$ \\
\hline Entrepreneur & $0.041^{* * *}$ & $(6.53)$ & $4.1 \%$ \\
\hline Employed part-time & $-0.672 * * *$ & $(51.33)$ & $-49.0 \%$ \\
\hline Self-Employed full time & $-0.057 * * *$ & $(5.89)$ & $-5.6 \%$ \\
\hline Self-Employed part time & $-0.363 * * *$ & $(25.89)$ & $-30.4 \%$ \\
\hline Woman*part time & $-0.281 * * *$ & $(19.44)$ & $-24.5 \%$ \\
\hline Rural & $-0.210 * * *$ & (40.99) & $-19.0 \%$ \\
\hline $\begin{array}{l}\text { observations } \\
\text { R-squared }\end{array}$ & $\begin{array}{r}83000 \\
0.419\end{array}$ & & \\
\hline
\end{tabular}

